\title{
Shark attack: the emergency presentation and management
}

\author{
Conor Gouk, ${ }^{1}$ Daman Pasricha, ${ }^{2}$ Sharanya Lingathas ${ }^{2}$
}

${ }^{1}$ Department of Orthopaedics, Gold Coast University Hospital, Gold Coast, Queensland, Australia

${ }^{2}$ Bond Medical School, Gold Coast, Queensland, Australia

\section{Correspondence to}

Dr Conor Gouk,

c.j.gouk.06@aberdeen.ac.uk

Accepted 2 October 2015
CrossMark

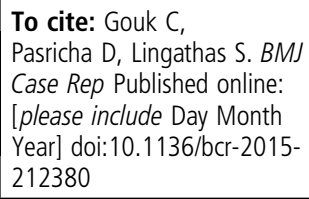

\section{DESCRIPTION}

A previously healthy 32-year-old man, a bodyboarder, was transported to hospital by primary retrieval helicopter, within $2 \mathrm{~h}$ of a shark attack injuring both legs. Tourniquets were applied bilaterally to decrease haemorrhage. En route to hospital he was intubated with an endotracheal tube due to severe agitation from acute blood loss (figures 1 and 2).

On arrival, the patient was transferred directly from helipad to theatre. Observations suggested significant blood loss (systolic blood pressure (BP) $<90 \mathrm{~mm} \mathrm{Hg}$, pulse rate (PR) $>130 \mathrm{bpm}$ ), prompting initiation of rational thromboelastometry (ROTEM)-guided massive transfusion. ${ }^{1}$ Complete transfusion consisted of $1 \mathrm{~L}$ normal saline, $10 \mathrm{U}$ packed red blood cells, $1 \mathrm{U}$ platelets, $9 \mathrm{U}$ cryoprecipitate, $1 \mathrm{U}$ fresh frozen plasma and $4 \mathrm{~g}$ fibrinogen concentrate. This resulted in haemodynamic stability (BP

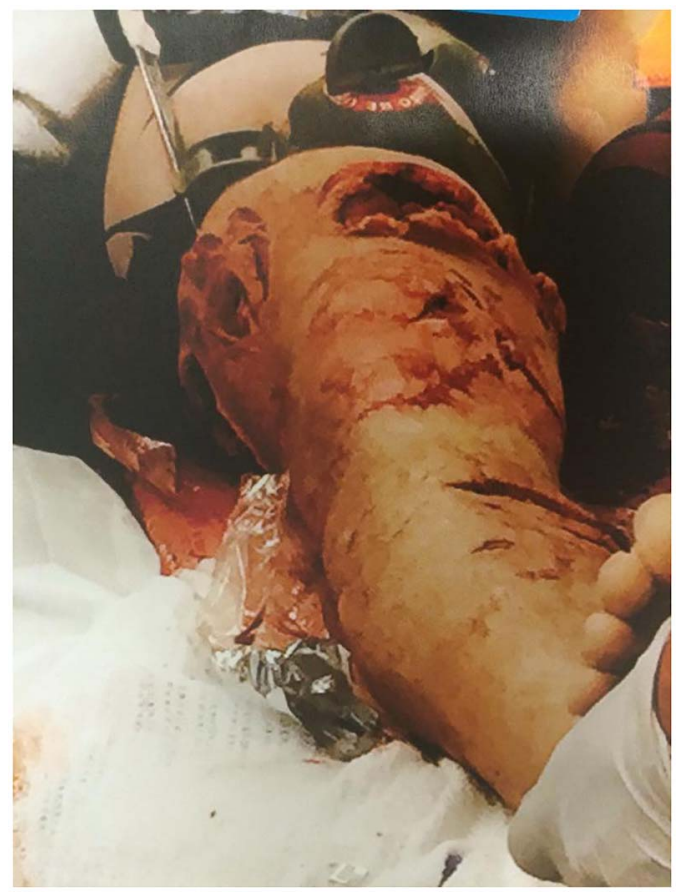

Figure 1 Right leg wounds with tourniquet applied to thigh; picture taken on arrival to hospital.
120/60 mm Hg, PR $125 \mathrm{bpm}$ ) allowing for initiation of lifesaving surgery within $1 \mathrm{~h}$ of arrival.

Initial intraoperative exploration revealed an extensive laceration on the left leg and a smaller medial thigh wound on the right leg (figure 3). All wounds were irrigated and debrided. Owing to the injury location, the left popliteal artery was visualised but found to be uninjured, however, immediate thrombectomy was required for a left popliteal vein thrombus. X-rays revealed teeth marks to the left femur and an avulsed fibular head (figures 4 and 5). Prophylactic antibiotics (cephazolin, metronidazole and gentamicin) were administered. The patient was admitted to intensive care unit.

In the past two decades, 186 shark attacks have occurred in Australian waters, $63 \%$ of these resulting in injury, and $11.8 \%$ resulting in death. The rising incidence is strongly correlated with increasing numbers of people entering the water. ${ }^{2}$

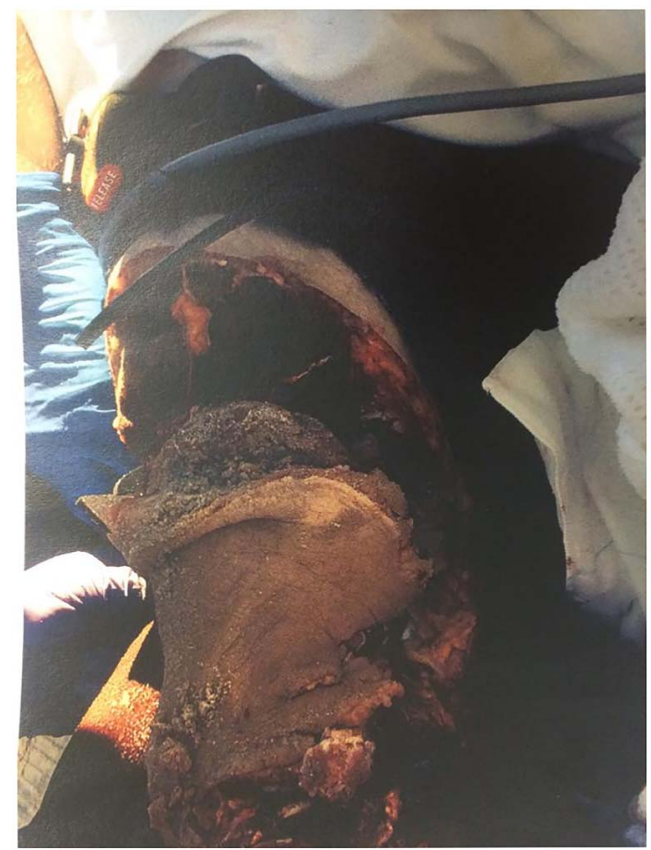

Figure 2 Left leg wounds with tourniquet applied, showing extensive injury to the thigh; picture taken on arrival to hospital. 


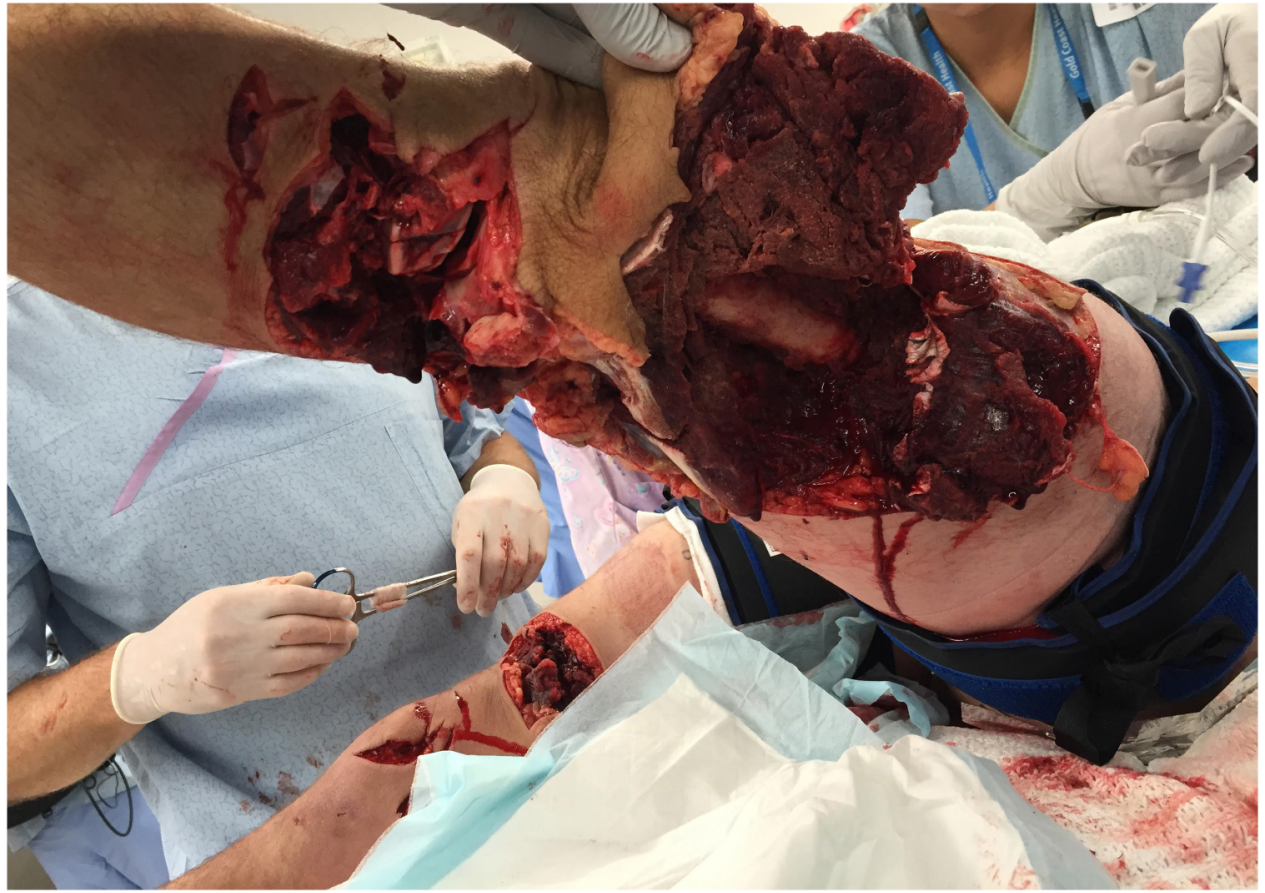

Figure 3 Initial intraoperative image of the patient's injuries. Left leg had an extensive laceration from anteromedial distal thigh extending laterally down to the fibula with an avulsed fracture of the fibula head, transected common peroneal and tibial nerves, exposed popliteal fossa and knee joint, damaged vastus lateralis muscle and bite marks on the femur. Right leg had a smaller open wound on the medial thigh.

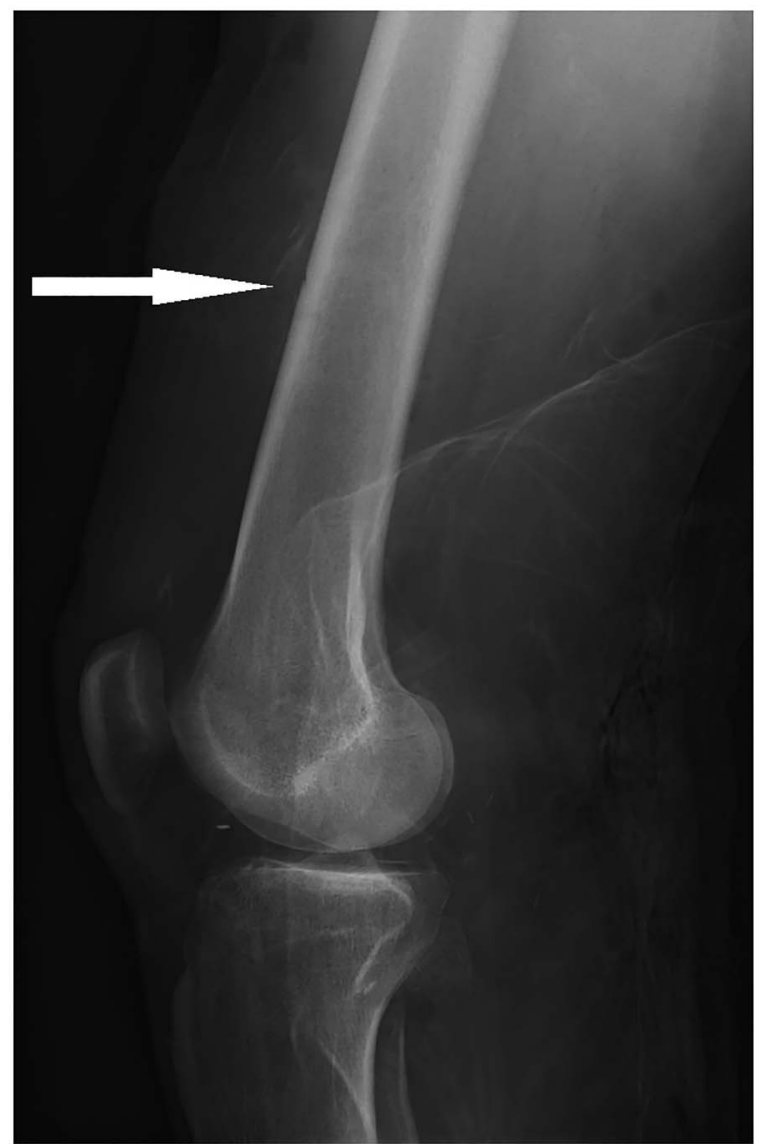

Figure 4 Plain lateral radiograph of left femur and knee displaying shark bites on anterior surface of femur and avulsed fibular head, indicated with arrow.

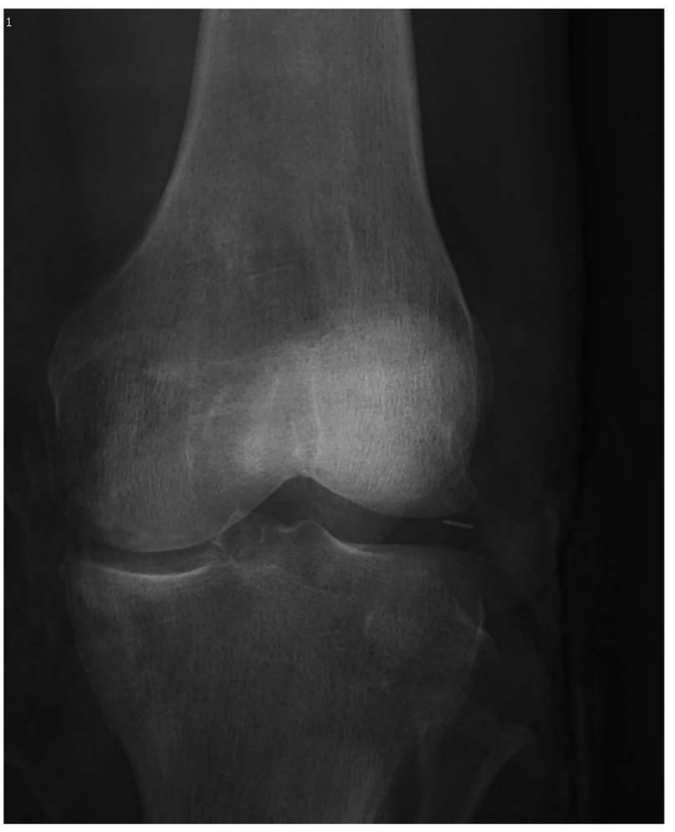

Figure 5 Plain anteroposterior radiograph of the left knee joint displaying an avulsed fracture of the fibula head.

\section{Learning points}

- Importance of prompt identification and initiation of treatment in the setting of acute blood loss.

- Importance of rapid response and retrieval times, in optimising patient outcomes.

- Importance of combining a focused history and examination with radiological adjuncts in a trauma setting. 
Acknowledgements The authors would like to thank the air ambulance crew.

Competing interests None declared.

Patient consent Obtained.

Provenance and peer review Not commissioned; externally peer reviewed.

\section{REFERENCES}

1 Whiting P, Al M, Westwood M, et al. Viscoelastic point-of-care testing to assist with the diagnosis, management and monitoring of haemostasis: a systematic review and cost-effectiveness analysis. Health Technol Assess 2015;19:1-228.

2 West JG. Changing patterns of shark attacks in Australian waters. Mar Freshwater Res 2011;62:744-54.

Copyright 2015 BMJ Publishing Group. All rights reserved. For permission to reuse any of this content visit http://group.bmj.com/group/rights-licensing/permissions.

BMJ Case Report Fellows may re-use this article for personal use and teaching without any further permission.

Become a Fellow of BMJ Case Reports today and you can:

- Submit as many cases as you like

- Enjoy fast sympathetic peer review and rapid publication of accepted articles

- Access all the published articles

- Re-use any of the published material for personal use and teaching without further permission

For information on Institutional Fellowships contact consortiasales@bmjgroup.com

Visit casereports.bmj.com for more articles like this and to become a Fellow 